\title{
Effect of seed dormancy breaking and seed priming treatments on germination, seedling growth and chemical composition of Canna indica $\mathrm{L}$.
}

\author{
Samah Mostafa El-Sayed and Nahed Galal Abd El-Aziz
}

Ornamental Plants and Woody Trees Dept., National Research Centre, Dokki, Giza, Egypt. Received: 12 Oct. 2020 / Accepted 11 Dec. 2020 / Publication date: 15 Dec. 2020

\begin{abstract}
This study was carried out to test the effect of soaking the seeds of Canna indica in concentrated sulfuric acid (CSA) for (30 and $60 \mathrm{~min}$.) and freeze-thaw technique (F-Th) (3 and 6 cycles) as seed dormancy breaking in addition to the control and /or hydrogen peroxide $\left(\mathrm{H}_{2} \mathrm{O}_{2}\right)$ at concentrations $(10,20$ and 30 $\mathrm{mM})$ and polyethylene glycol $\left(\mathrm{PEG}_{4000}\right)$ at $(10,15$ and $20 \%)$ as seed primer breaking in addition to the control on overcome the physical dormancy of Canna indica seeds and enhancement the vegetative growth traits and some biochemical component resulted seedlings. The obtained results clarified that the treatment $\mathrm{F}_{-} \mathrm{Th}_{3}$ increased the germination percentage (GP \%), seed vigor index (SVI) in both seasons and germination rate index (GRI \%/day) in the second season; but the lowest mean value of mean germination time (MGT day) was obtained from $\mathrm{CSA}_{60}$. Priming the seeds with $\mathrm{H}_{2} \mathrm{O}_{2}$ at $10 \mathrm{mM}$ significantly increased the same traits in both seasons, but the treatment with $\mathrm{H}_{2} \mathrm{O}_{2}$ at $30 \mathrm{mM}$ and PEG $20 \%$ gave the lowest mean value for MGT in the first and second seasons, respectively. The interaction of $\mathrm{F}-\mathrm{Th}_{3}+\mathrm{H}_{2} \mathrm{O}_{2} 10 \mathrm{mM}$ significantly increased GP\% in the two seasons and GRI in the second season, but, treating the seeds with $\mathrm{CSA}_{60}+\mathrm{H}_{2} \mathrm{O}_{2} 10 \mathrm{mM}$ significantly increased GRI in the first season, while the lowest MGT was obtained from seeds treated with $\mathrm{F}-\mathrm{Th}_{6}+\mathrm{PEG}$ at $15 \%$ and $\mathrm{CSA}_{60}+$ control in the first and second seasons, respectively. All the vegetative growth parameters and biochemical analysis recorded the highest mean values with treatment $\mathrm{F}-\mathrm{Th}_{6}$ in both seasons. With regard to seed priming treatment, the highest mean value of aerial part length, aerial part fresh weight, antioxidant activity in both aerial part and root, chlorophyll a and carotenoid were recorded with $\mathrm{H}_{2} \mathrm{O}_{2}$ at $20 \mathrm{mM}$ treatment, and chlorophyll b gave the highest value with PEG $15 \%$ treatment in both seasons while the treatment $\mathrm{H}_{2} \mathrm{O}_{2}$ at $10 \mathrm{mM}$ significantly increased root length, root fresh weight, carbohydrates \% in both aerial part and root in the first season. Concerning the interaction treatments, it was found that the treatment $\mathrm{F}_{-} \mathrm{Th}_{6}+$ PEG $15 \%$ gave the highest value for most of vegetative growth parameters, photosynthetic pigments content and carbohydrates \% in aerial part; but carbohydrate \% in roots recorded the highest value with treatment $\mathrm{F}-\mathrm{Th}_{6}+\mathrm{H}_{2} \mathrm{O}_{2}$ at $10 \mathrm{mM}$, and antioxidant activity increased with $\mathrm{F}-\mathrm{Th}_{6}+\mathrm{H}_{2} \mathrm{O}_{2}$ at $20 \mathrm{mM}$ in both parts of the plant in the first and second seasons.
\end{abstract}

Keywords: Canna indica, physical dormancy, germination, freeze-thaw, sulfuric acid, seed priming, hydrogen peroxide and polyethylene glycol, seedling growth and chemical composition.

\section{Introduction}

Canna is the only genus following family Cannaceae and belongs to tropical and sub-tropical regions of southern United States and south to northern Argentina and the Philippines.

Canna indica is one of canna species which called Indian shot or Canna lily, the plant have attractive foliage, dark green colored with colorless margin and veins with ovate shape, the leaves are simple, alternate and spiral. They have petioles spreading downward to form a sheathing base around stem (Pullaiah, 2006 and Ciciarelli, 2012). The plant has pseudostem reaches up to 1.5 to $2 \mathrm{~m}$ in height, glabrous, upstanding, vigorous and cylindrical covered with sheathing leaves bases which are light green, and the mature plant has brown rhizome with thick outer cover and thick creamy white roots. The flowers are red, single or in pair, the diameter of flowers 4-6 cm (Ciciarelli, 2012).

Canna indica plant has many important uses such as: Ornamental plant because of its attractive shape, so the plant is used in parks, gardens and road landscape (Kessler, 2007), used in traditional remedy for the treatment of many complaints, the pharmacological studies presented that this plant has a positive effect as anthelmintic, antibacterial, antimicrobial, antiviral, antidiabetic, antidiarrheal, anti-

Corresponding Author: Samah Mostafa El-Sayed, Ornamental Plants and Woody Trees Dept., National Research Centre, Dokki, Giza, Egypt. E-mail: mu.ali@nrc.sci.eg 
inflammatory and antioxidant (Kanase and Vishwakarma, 2018), Canna indica has edible large rhizomes up to $60 \mathrm{~cm}$ (FAO, 2016) which is containing easily digestible starch therefore it was found suitable for the health of babies as food, the color of Canna flowers was extracted to use as food dye (Vankar and Srivastava, 2018) and Canna indica can be used as phytoremediation agent to mitigate the higher pollution in the soil (Gunarathna et al., 2016). Canna inica plant can be propagated vegetatively by rhizome division and sexually by seeds. But the propagation by rhizome division may cause damage for the plant when separating this rhizome, and also this way of propagation gives limited numbers of resulted plants. Whereas, the propagation by seeds is an important in genetic improvement and production of different hybrids as well as the production of large amount of seedlings without damaging the mother plant. The propagation by seeds is facing the physical dormancy problem which is caused mechanical strength and water constraint is assigned to the exotestal layers of malpighian cells which works as a physical barrier to imbibition, so the seeds do not imbibe water they remain in hard status and not swollen (Graven et al., 1997). There are different ways to overcome the physical dormancy, among them chemical scarification with sulfuric acid $\left(\mathrm{H}_{2} \mathrm{SO}_{4}\right)$ which is causes softening in the seed coat (Channegowda et al., 2001). The other method to overcome the physical dormancy is a simple method, called freeze-thaw technique, which is based on placing the seeds of plants in the freezing condition $\left(\mathrm{CO}_{2}\right.$ snow, dry ice, ultra-low freezer, liquid air and liquid nitrogen) until freezing and then transferring them directly to hot water to make shock which lead to make cracks in the seed coat which resulted from expansion and constriction (Tiryaki and Topu, 2014). Both of the treatments permitting the penetration of water in the seeds suffering from physical dormancy and germination easily.

Seed priming technique is a technique in which seeds are soaked in a certain solution for a period of time (no radical emergency or breaks in seed coat) and then planted for germination (Paparella et al., 2015).

Some studies have shown the effect of freezing-thawing techniques on breaking the physical seed dormancy, but there is a great lack of information about the effect of this method on the resulting seedlings in terms of vegetative characteristics and chemical components, so the aim of the research was to document the effect of seed dormancy breaking and/or seed priming treatments on seed germination, seedling growth and chemical composition of Canna indica L. plant.

\section{Material and Methods}

The experiment was carried out in a semi-shade area in the National Research Centre, Dokki, Giza, Egypt, during two seasons June 2018 and 2019. The Canna Indica capsule-shaped fruit the seeds were fully ripe, brown to black color. It was collected manually from the mature plants grown in Experimental Research Station of National Research Centre, Nubaria, El Behera governorate, Egypt. The present study was conducted to find out the effect of pre-sowing treatment including chemical scarification with concentration sulfuric acid (CSA) and freeze-thaw (F-Th) technique on physical dormancy overcoming of Canna Indica L. seeds and/or effect of seed priming with hydrogen peroxide $\left(\mathrm{H}_{2} \mathrm{O}_{2}\right)$ and polyethylene glycol $\left(\mathrm{PEG}_{4000}\right)$ on improvement of seeds germination and growth of resulted seedlings.

\section{Experimental procedures}

The seeds were sterilized by dipping in a $0.1 \% \mathrm{HgCl}_{2}$ solution for $10 \mathrm{~min}$.

\subsection{Seed dormancy breaking treatment:}

The sterilized seeds were soaked in concentrated sulfuric acid for two durations $30 \mathrm{~min}$. $\left(\mathrm{CSA}_{30}\right)$ and $60 \mathrm{~min}$. $\left(\mathrm{CSA}_{60}\right)$, after that the treated seeds were rinsed with distilled water. Freeze-thaw treatment was carried out after sterilization by freezing the seeds in the deep freezer at $-5^{\circ} \mathrm{C}$ for $24 \mathrm{~h}$ and putting them immediately in hot water $\left(95-100^{\circ} \mathrm{C}\right)$, repeated the steps 3 times $(3$ cycles $)\left(\mathrm{F}-\mathrm{Th}_{3}\right)$ and 6 times $(6$ cycles) $\left(\mathrm{F}-\mathrm{Th}_{6}\right)$ and the untreated seeds $(\mathrm{C} 1)$.

\subsection{Seed priming treatments:}

After seeds dormancy breaking treatment, the seeds were soaked in priming solutions including hydrogen peroxide $\left(\mathrm{H}_{2} \mathrm{O}_{2}\right)$ at three concentrations 10,20 and $30 \mathrm{mM}$ and Polyehtylene glycol ( $\left.\mathrm{PEG}_{4000}\right)$ 
at three concentrations 10,15 and 20\% for $24 \mathrm{~h}$. All Priming solutions were prepared in distilled water and the untreated seeds $(\mathrm{C} 2)$.

The interaction treatments were 35 treatment including seed dormancy breaking treatment ( 5 treatments) X seed priming treatments (7 treatment).

The experiment was laid out in completely randomized design. The previous treatments were done with three replicates for each treatment $(1$ replicate $=20$ seeds). Each seed was sown in plastic pot $10 \mathrm{~cm}$ diameter; these pots were filled with mixture of peatmoss and sand $(2: 1 \mathrm{v} / \mathrm{v})$. The physical and chemical properties of peatmoss and sand are shown in Tables (1\&2) according to Chapman and Pratt (1961).

Table 1: Physical properties of sand

\begin{tabular}{|l|l|l|l|l|}
\hline Soil sample & Coarse sand \% & Fine sand\% & Silt\% & Clay\% \\
\hline Sand & 75 & 16.5 & 3.2 & 5.3 \\
\hline
\end{tabular}

Table 2: Chemical analysis of peatmoss and sand

\begin{tabular}{|c|c|c|c|c|c|c|c|c|c|}
\hline Soil sample & Sp\% & pH & Ash\% & Organi & tter\% & N\% & & P\% & K\% \\
\hline Peatmoss & 35 & $3-3.5$ & $1-5$ & & & 2.4 & & 0.05 & 1.7 \\
\hline \multirow{3}{*}{ Sand } & E.C.(1:1) ds/m & $\mathrm{pH}_{(1: 1)}$ & \multicolumn{3}{|c|}{ Anions (meq/l) } & \multicolumn{4}{|c|}{ Cations (meq/l) } \\
\hline & \multirow{2}{*}{0.32} & \multirow{2}{*}{7.62} & $\mathrm{HCO}_{3}$ & Cl & $\mathrm{SO}_{4}$ & $\mathbf{C a}$ & Mg & $\mathrm{Na}$ & $\mathbf{K}$ \\
\hline & & & 0.5 & 0.72 & 0.88 & 0.5 & 0.4 & 0.9 & 0.2 \\
\hline
\end{tabular}

The experiment continued for 35 days and then the following data were collected and recorded:

\section{Germination traits}

2.1. Germination percentage (GP\%) which was calculated as the cumulative number of germinated seeds with normal radicles by using the equation as described by Scott et al. (1984): GP $=\Sigma \mathrm{n} / \mathrm{N} \times 100$, where $\mathrm{n}$ is number of germinated seeds at each counting and $\mathrm{N}$ is total seeds in each treatment.

\subsection{Germination rate index (GRI) (\%/ day)}

$\mathrm{GRI}=\mathrm{G} 1 / 1+\mathrm{G} 2 / 2+\cdots+\mathrm{Gx} / \mathrm{x}$, where $\mathrm{G} 1=$ Germination percentage $\times 100$ at the first day after sowing, G2 $=$ Germination percentage $\times 100$ at the second day after sowing (Esechi, 1994).

\subsection{Mean germination time (MGT) (Day)}

MGT $=\Sigma f \cdot x / \Sigma f$, Where $f$ is the number of seeds that had germinated on day $\mathrm{x}$ and $\mathrm{x}$ is the number of days counted from the beginning of germination (Orchard, 1977).

2.4. Seedling vigor index $($ SVI) $=$ Mean seedling length $\times$ Percentage of seed germination, these indices are given by Abdul-Baki and Anderson (1973).

\section{Vegetative traits}

The data recorded: Aerial part length, Root length, Areal part fresh weight and Root fresh weight.

\section{Chemical composition}

Determination of photosynthetic pigments in leaves (mg/g FW) according to Moran (1982). Carbohydrates (\%) were determined from the dry areal parts and roots according to Dubois et al. (1956). Antioxidant activity (\%) in both areal parts and roots by 2, 2 diphenyl-1-picrylhydrazyl (DPPH) according to Burits and Bucar (2000).

\section{Statistical analysis}

The recorded Data statistically analyzed using the Least Significant Difference (L.S.D) test at the 5\% level as described by Little and Hills (1978). All the statistical analyses were performed by using CoStat (CoHort software, Monterey, CA, USA) V6.4 (2005). 


\section{Results and Discussion}

\section{Germination traits}

The data showed in Tables $(3 \& 4)$ pointed that the treatment of seeds dormancy breaking with F$\mathrm{Th}_{3}$ significantly increased GP (81.86 and 85.71\%) and SVI (1655.53 and 1756.84) in both seasons, respectively, compared with the control and other treatments. The seeds treated with $\mathrm{F}-\mathrm{Th}_{3}$ were the most delayed in germination (18.36 and 18.06 days in the first and second seasons, respectively), on the contrary; the treatment that helped the seeds to germinate early was concentrated $\mathrm{CSA}_{60}$ giving mean values (11.81 and 12.71 days) in the first and second seasons, respectively. regarding the seeds treated with $\mathrm{CSA}_{60}$ significantly increased GRI\% (9.59\%/ day) in the first season, while in the second season treated the seeds with $\mathrm{F}-\mathrm{Th}_{3}$ significantly increased GRI\% $(8.95 \% /$ day) compared with the control and other treatments. The untreated seeds gave the lowest mean values for all mentioned traits.

Table 3: Effect of seed dormancy breaking and seed priming treatment on the germination percentage GP (\%) and germination rate index GRI (\%/day) of Canna indica seeds during $1^{\text {st }}$ and $2^{\text {nd }}$ season

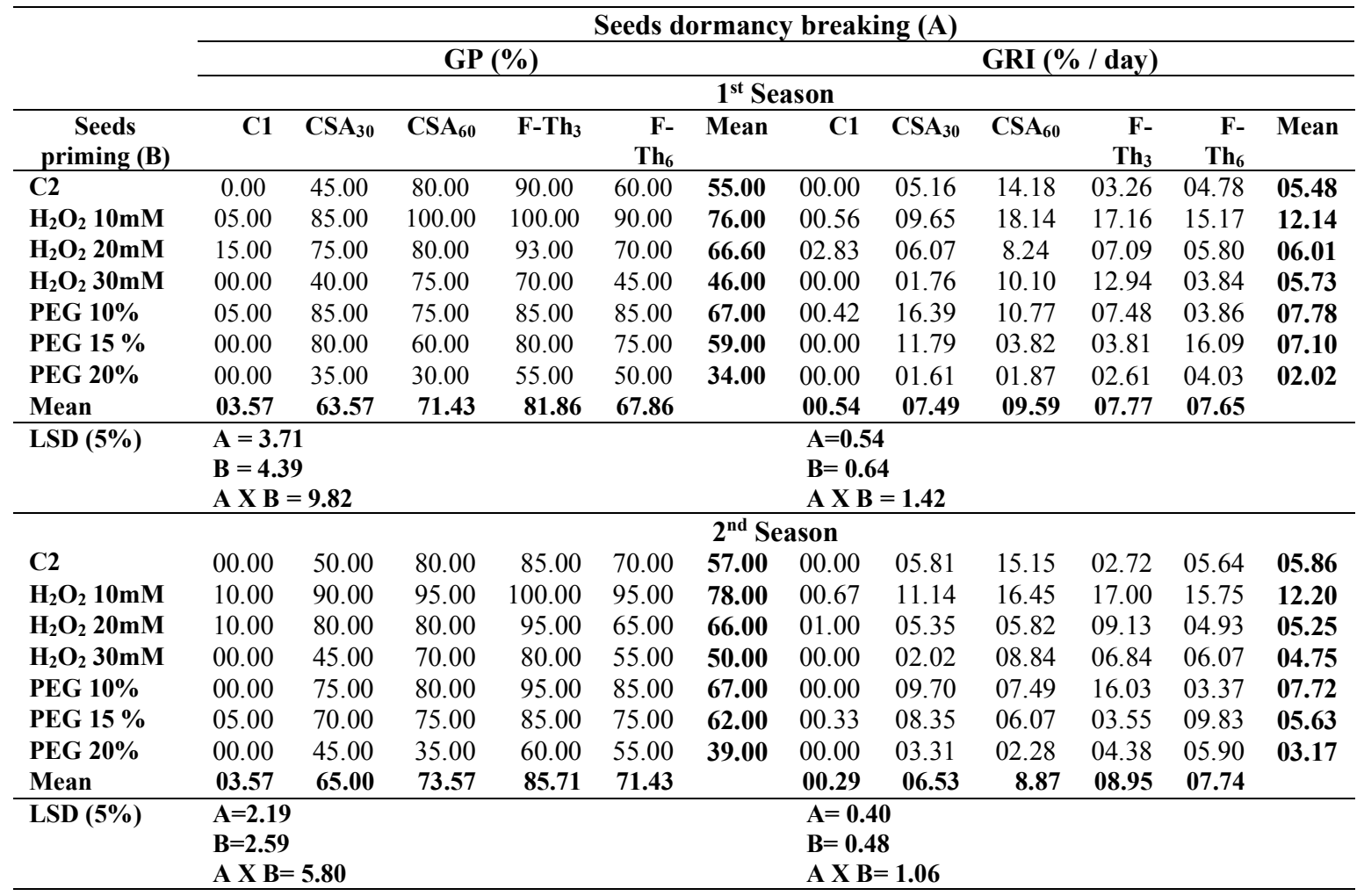

It is noticed that the previous results cleared the germination of Canna indica seeds was improved $\mathrm{F}-\mathrm{Th}_{3}$, it maybe a result of cracks in the seed coat which were caused by expansion and contraction which occurred due to repeating the shock of frozen seeds in the boiling water, which helped the water to penetrate easily into the seed (Zeng et al., 2005). These results are in agreement with Stout (1990) who stated that freeze-thaw treatment decreased the dormancy of alfalfa seed from 60 to $14 \%$. And Tiryaki and Topu (2014) who found that freeze-thaw treatment increased germination percentage and germination rate of Lupinus alba.

The following treatment which improved canna seed germination is $\mathrm{CSA}_{60}$ which caused chemical erosion of seed coat (Hu et al., 2009). The same results were obtained in Prosopis juliflora and Dodonaea viscosa (Nasr et al., 2013) and Teucrium chamaedrys L. (Farahani et al., 2014). 
Table 4: Effect of seed dormancy breaking and seed priming treatments on the mean germination time MGT(day) and seed vigor index (SVI) on Canna indica seeds during $1^{\text {st }}$ and $2^{\text {nd }}$ season

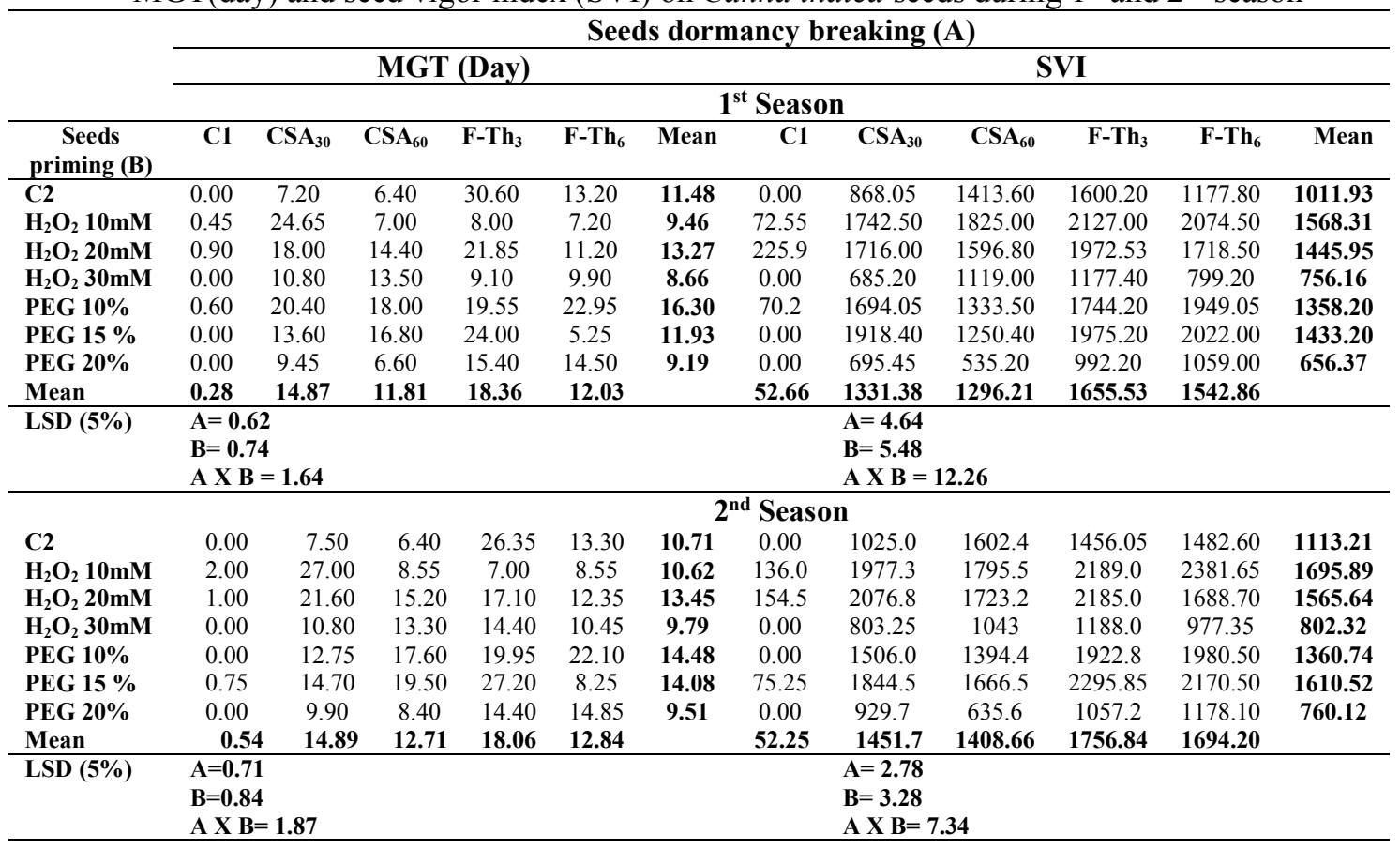

Concerning the effect of seeds priming treatments the data in Tables ( 3 and 4 ) showed that treated the seeds with $\mathrm{H}_{2} \mathrm{O}_{2}$ at $10 \mathrm{mM}$ significantly increased GP (76 and 78\%), GRI (12.14 and 12.20\%/day), SVI (1568.31 and 1695.89), respectively, in the first and second seasons. The seeds treated with $\mathrm{H}_{2} \mathrm{O}_{2}$ at $30 \mathrm{mM}$ followed by PEG $20 \%$ and then $\mathrm{H}_{2} \mathrm{O}_{2}$ at $10 \mathrm{mM}$ were the least significant MGT giving mean values (8.66, 9.19 and 9.46 days, respectively) in the first season. In the second season, the least value (9.51 days) was obtained from treatment PEG 20\% followed by (9.79 days) which obtained from treatment $\mathrm{H}_{2} \mathrm{O}_{2}$ at $30 \mathrm{mM}$. Whilst, treatment with PEG with $10 \%$ significantly increased with MGT giving (16.3 and 14.48 day) in both seasons as compared with other treatments.

Improvement of germination traits in primed seeds could be linked to physiological effects of pre-treatment. Indeed, primed seeds exhibited a faster imbibition as compared to untreated seeds.

The plant produces active oxygen species (AOS) as intermediates of cellular metabolism under normal conditions and are generated in the presence of biotic and abiotic stresses, when AOS reach dangerous levels, they can be eliminated by antioxidant enzymes (AOE) such as catalases and peroxidases (Breusegem et al. 2001), The pretreating of seeds with $\mathrm{H}_{2} \mathrm{O}_{2}$ in a harmless dose and duration may have improve the germination and seedling growth by moving the mechanisms of defense (Çavusoglu and Kabar, 2010). Nagarajan et al. (2005) reported that enhancement in the primed seed germination with PEG might be directly related to the modification of seed water relations. Furthermore, this study therefore suggested that vacuums created inside the seed as a result of priming made water flow easier, thus contributing to tissue hydration. These results are in harmony with Salah et al. (2015) on Oryza sativa L. and Mirmazloum et al. (2020) on Carum carvi L.

Regarding the effect of interaction between the seed dormancy breaking and seed priming treatments on the germination traits, the results of GP showed that the seeds treated with $\mathrm{CSA}_{60}$ or F$\mathrm{Th}_{3}+\mathrm{H}_{2} \mathrm{O}_{2}$ at $10 \mathrm{mM}$ gave the highest significant increase with the same value $(100 \%)$ in the first season; whereas, in the second season the highest germination percentage $(100 \%)$ were obtained when seeds were treated with $\mathrm{F}-\mathrm{Th}_{3}+\mathrm{H}_{2} \mathrm{O}_{2}$ at $10 \mathrm{mM}$ compared with other treatments.

The seeds which were treated with concentrated $\mathrm{CSA}_{60}+\mathrm{H}_{2} \mathrm{O}_{2}$ at $10 \mathrm{mM}$ significantly increased GRI (18.14\%/day) in the first season, while in the second season the highest mean value was obtained from $\mathrm{F}-\mathrm{Th}_{3}+\mathrm{H}_{2} \mathrm{O}_{2}$ at $10 \mathrm{mM}$ giving mean value $(17.00 \%$ /day) compared with the other treatments. 
Treating the seeds with F-Th $_{6}+$ PEG $15 \%$ gave the earliest MGT with mean value (5.25 days) in the first season, while in the second season treating the seeds with CSA60+ C2 led to the earliest MGT with mean value (6.4days)

The highest mean value of SVI (2127.00) resulted from seeds treated with $\mathrm{F}-\mathrm{Th}_{3}+\mathrm{H}_{2} \mathrm{O}_{2}$ at $10 \mathrm{mM}$ in the first season, while in the second season the highest mean value (2381.65) was obtained from treatment $\mathrm{F}_{-}-\mathrm{Th}_{6}+\mathrm{H}_{2} \mathrm{O}_{2}$ at $10 \mathrm{mM}$.

\section{Vegetative traits}

The data presented in Tables (5 and 6) showed that the seeds scarified by F-Th 6 significantly increased aerial part length $(13.24$ and $12.96 \mathrm{~cm})$, root length $(9.05$ and $10.42 \mathrm{~cm})$, fresh weight of aerial part $(0.49$ and $0.54 \mathrm{~g})$ and roots fresh weight $(0.45$ and $0.43 \mathrm{~g})$ in the first and second season, respectively, compared with the control and other treatments. Whereas, the lowest mean value aerial part height $(11.04$ and $10.78 \mathrm{~cm})$, root length $(7.14$ and $8.03 \mathrm{~cm})$, fresh weight of aerial part $(0.39$ and $0.40 \mathrm{~g})$ and fresh weight of roots $(0.39$ and $0.34 \mathrm{~g})$ between the treatments from were obtained from seeds soaked in $\mathrm{CSA}_{60}$.

Regarding seeds priming treatments, treated seed with $\mathrm{H}_{2} \mathrm{O}_{2}$ at $20 \mathrm{mM}$ significantly increased aerial part length $(13.08 \mathrm{~cm})$ in the first season, the same treatment significantly increased aerial part fresh weight $(0.48$ and $0.51 \mathrm{~g})$ in the first and second seasons, respectively, compared with control and other treatments. While, treatment of $\mathrm{H}_{2} \mathrm{O}_{2}$ at $10 \mathrm{mM}$ caused significant increase in root length and root fresh weight $(8.34 \mathrm{~cm}$ and $0.42 \mathrm{~g})$, respectively, in the first season compared with control and other treatments. In the second season, the highest significant value for aerial part length $(13.83 \mathrm{~cm})$, root length (10.08) and, root fresh weight $(0.44 \mathrm{~g})$ were obtained from treatment PEG at $15 \%$ compared with control and other treatments.

These results are demonstrated by El-Saifi et al., (2010) found that using PEG at 1.0MPa as seed priming has an enhancing effect on plant height and plant fresh weight of tomato seedlings

Table 5: Effect of seed dormancy breaking and seed priming treatment on the aerial part length $(\mathrm{cm})$ and root length $(\mathrm{cm})$ on the Canna indica seedlings during $1^{\text {st }}$ and $2^{\text {nd }}$ season

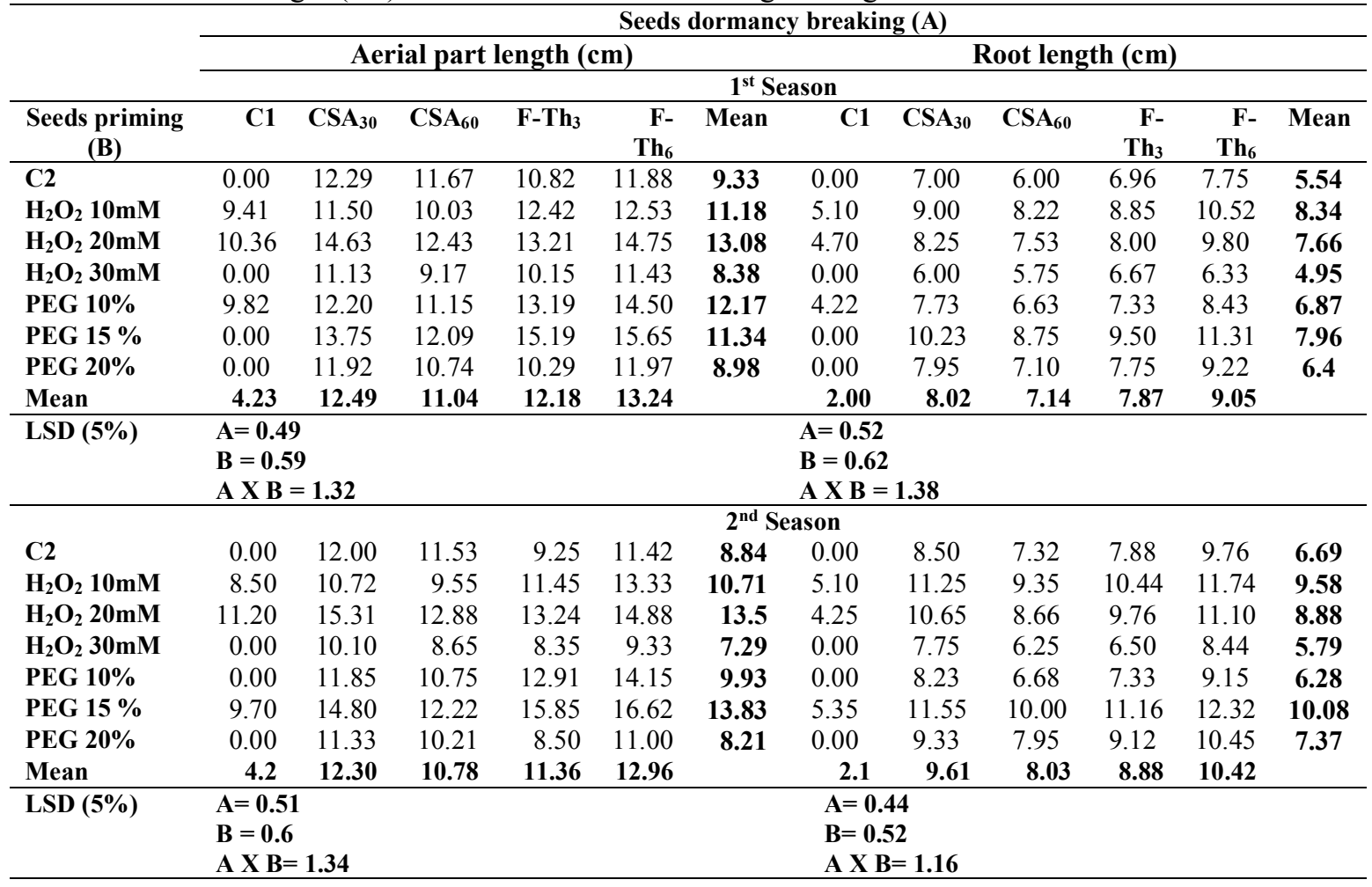


Table 6: Effect of seed dormancy breaking and seed priming treatment on the aerial part fresh weight $(\mathrm{g})$ and root fresh weight $(\mathrm{g})$ on the Canna indica seedlings during $1^{\text {st }}$ and $2^{\text {nd }}$ season

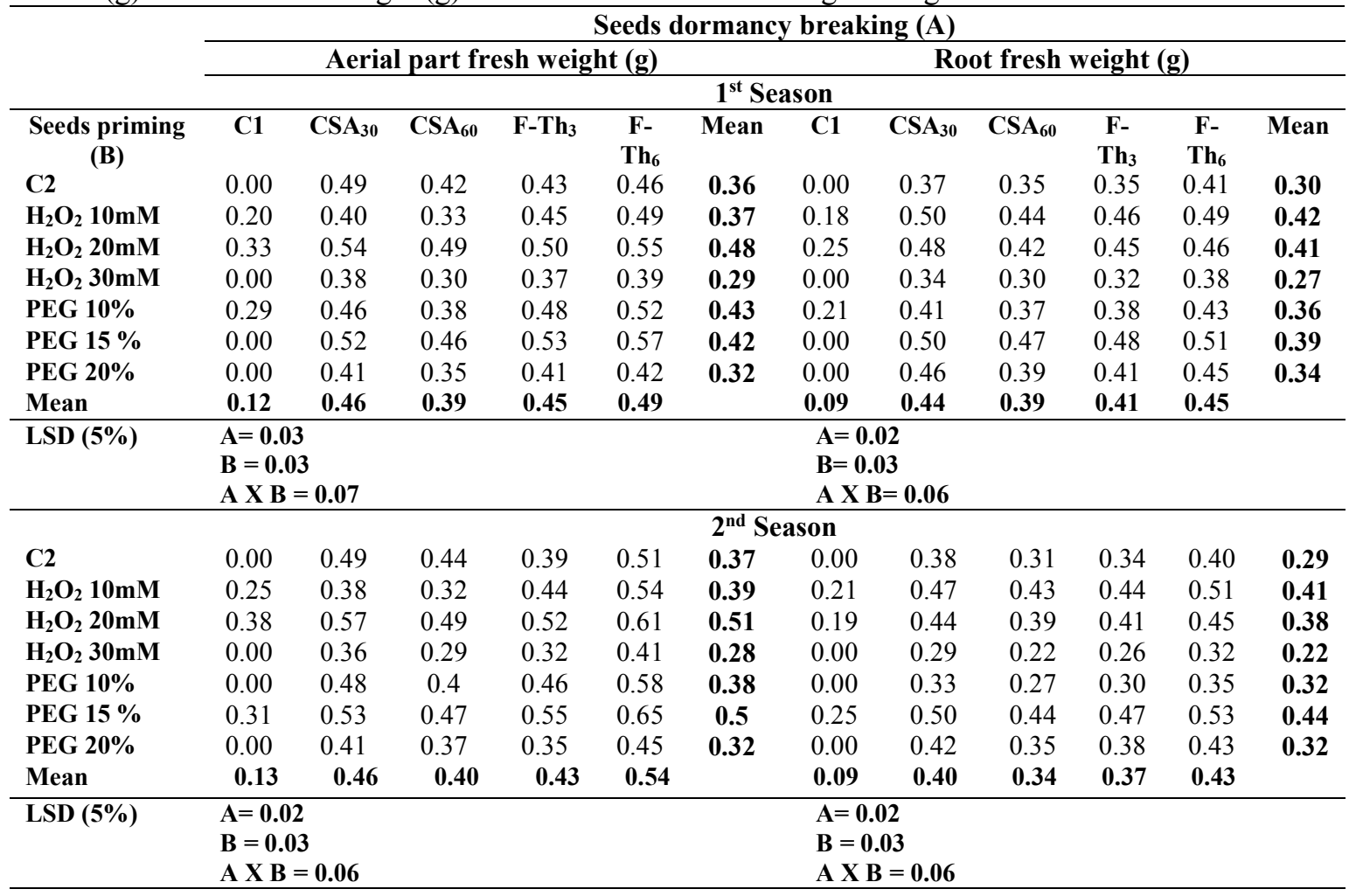

Santhy et al. (2014) stated that the pre-treatment for cotton seeds with $\mathrm{H}_{2} \mathrm{O}_{2}$ increased plant height, root length and seedling fresh weight as compared to control plants; and (Migahid et al., 2019) who found that the seeds of Silybum marianum (L.) treated with $\mathrm{H}_{2} \mathrm{O}_{2}$ gave the highest value for length and fresh weight of shoot and root. The increment in the vegetative traits caused by $\mathrm{H}_{2} \mathrm{O}_{2}$ as compared to the control plants may be due to $\mathrm{H}_{2} \mathrm{O}_{2}$ as pretreatment can increase ascorbat peroxidase (APX), peroxidase (POX) and ascorbate oxidase (AAO) (Barba-Espin et al., 2010), this raising in these enzymes correlate with increase in the growth of the seedlings (Cavusoglu and Kabar, 2010).

Concerning the interaction, the results showed that the treatment $\mathrm{F}-\mathrm{Th}_{6}+\mathrm{PEG}$ at $15 \%$ was the most effective for all parameters giving significant increase in aerial part length $(15.65$ and $16.62 \mathrm{~cm})$, root length $(11.31$ and $12.32 \mathrm{~cm})$, aerial part fresh weight $(0.57$ and $0.65 \mathrm{~g})$ and roots fresh weight $(0.51$ and $0.53 \mathrm{~g}$ ) in the first and second seasons, respectively, compared with control and other treatments.

\section{Chemical composition}

\subsection{Photosynthetic pigments content (mg/ g F.W.)}

The data showed in Figs $(1: a, b \& c),(2: a, b \& c)$ and $(3: a, b \& c)$ illustrated that the changes in photosynthetic pigments content for canna seedlings unfolding from the seeds which received previous treatment.

The photosynthetic pigments demonstrated high response in the leaves of seedlings resulted from treatment F-Th 6 giving values for chlorophyll a $(0.625$ and $0.685 \mathrm{mg} / \mathrm{g} \mathrm{F}$.W. $)$, chlorophyll b $(0.33$ and $0.362 \mathrm{mg} / \mathrm{g} \mathrm{F}$.W.) and carotenoids ( 0.232 and $0.226 \mathrm{mg} / \mathrm{g} \mathrm{F.W.),} \mathrm{respectively,} \mathrm{in} \mathrm{the} \mathrm{first} \mathrm{and} \mathrm{second}$ season, as compared to other treatments and the control.

Whereas, the results fluctuated between seed priming treatments. Where, it is for chlorophyll a and carotenoids the highest mean value $(0.544$ and $0.211 \mathrm{mg} / \mathrm{g} \mathrm{F.W.,} \mathrm{respectively)} \mathrm{where} \mathrm{obtained}$ from treatment $\mathrm{H}_{2} \mathrm{O}_{2}$ at the concentration $20 \mathrm{mM}$ in the $1^{\text {st }}$ season, but in the $2^{\text {nd }}$ season the highest mean values ( 0.609 and $0.239 \mathrm{mg} / \mathrm{g} \mathrm{F}$.W., respectively) obtained from treatment of PEG at $15 \%$. 


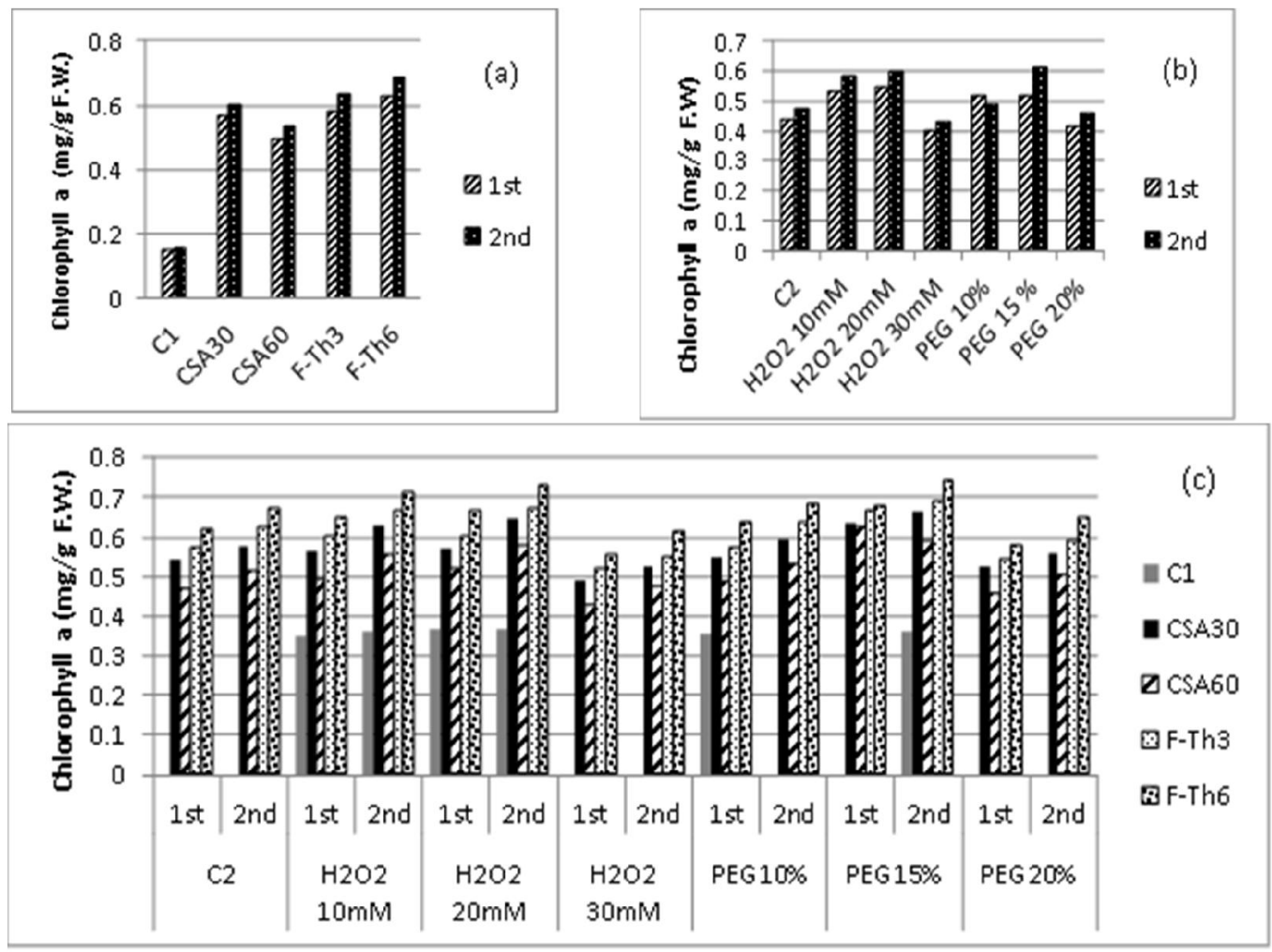

Fig. 1: Effect of seed dormancy breaking (a) and seed priming (b) treatment and their interaction (c) on chlorophyll a content in leaves of Canna indica seedlings (mg/g F.W.) during $1^{\text {st }}$ and $2^{\text {nd }}$ season.

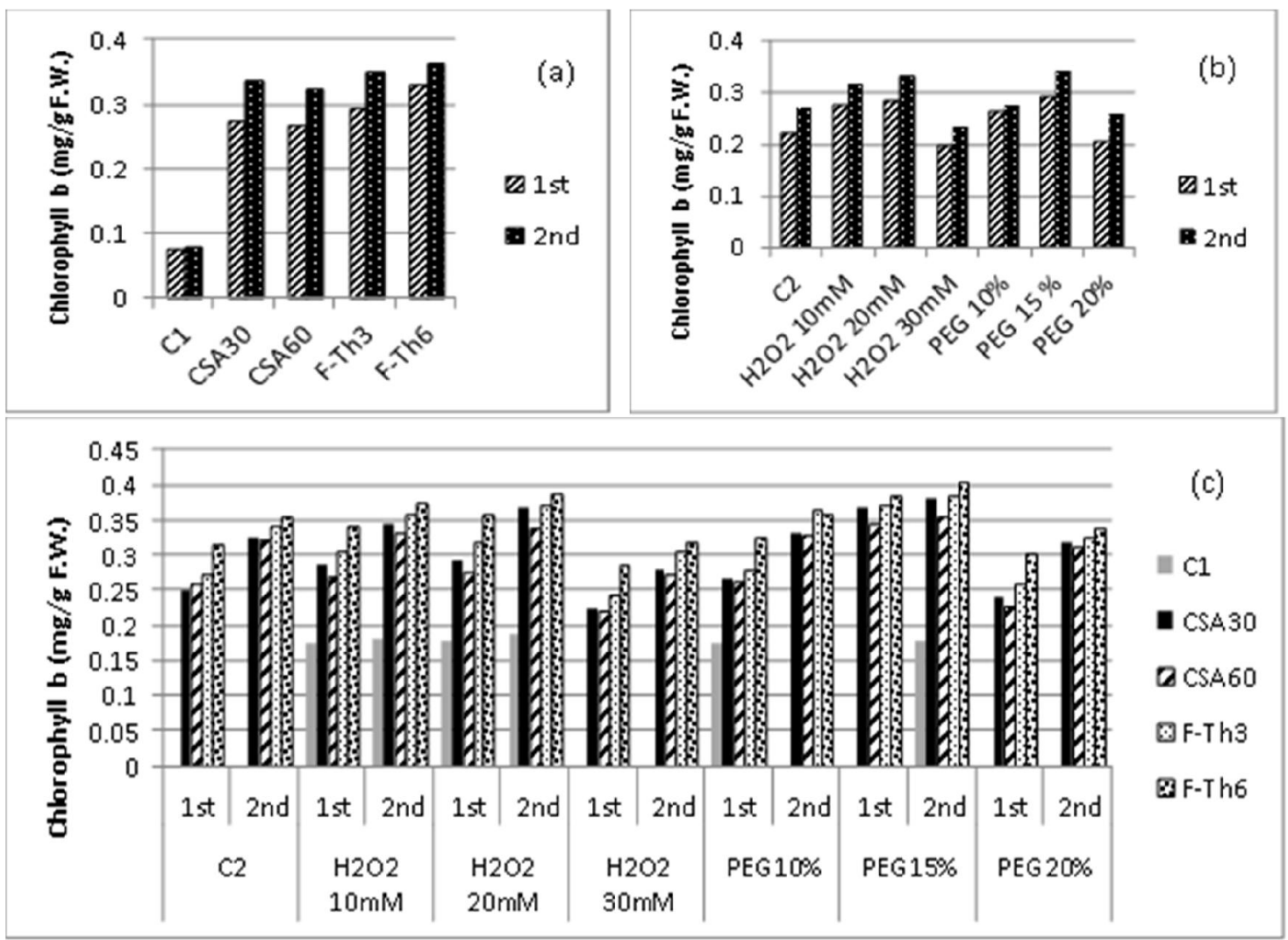

Fig. 2: Effect of seed dormancy breaking (a) and seed priming (b) treatment and their interaction (c) on chlorophyll b content in leaves of Canna indica seedlings ( $\mathrm{mg} / \mathrm{g} \mathrm{F}$.W.) during $1^{\text {st }}$ and $2^{\text {nd }}$ season 


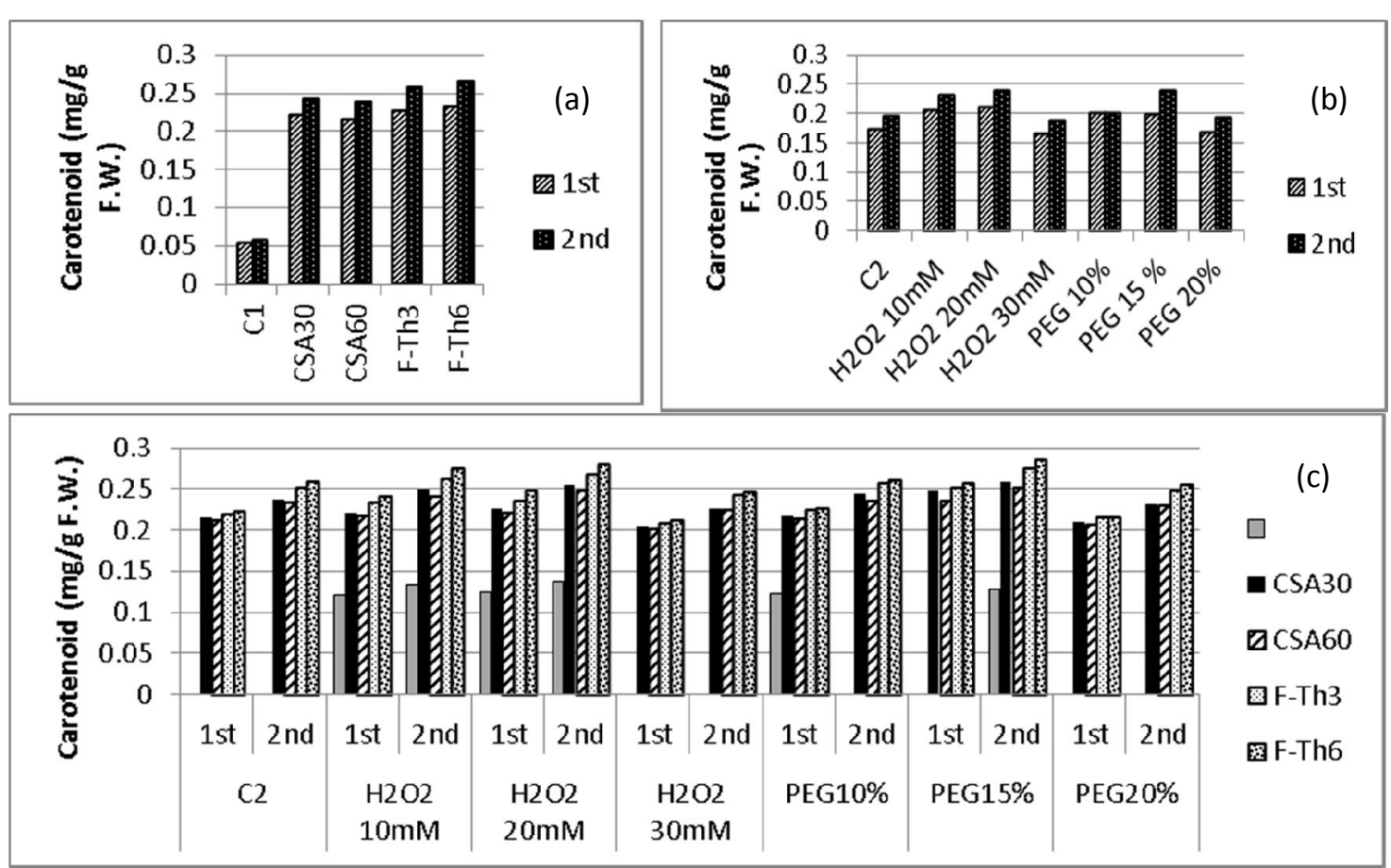

Fig. 3: Effect of seed dormancy breaking (a) and seed priming (b) treatment and their interaction (c) on carotenoid content in leaves of Canna indica seedlings (mg/g F.W.) during $1^{\text {st }}$ and $2^{\text {nd }}$ season

While, the treatment of PEG at $15 \%$ gave the highest mean values for chlorophyll $b$ ( 0.293 and $0.340 \mathrm{mg} / \mathrm{g} \mathrm{F}$.W.) respectively, in both seasons. This result is in agreement with El-Saifi et al. (2010) stated that using PEG increased chlorophyll a, b and carotenoid content, and Zhang et al. (2015) suggested that PEG treatment as seed priming increased chlorophyll a content as compared to control.

The interaction treatments gave different values, the highest mean value for chlorophyll $\mathrm{a}, \mathrm{b}$ and carotenoids $(0.679,0.384$ and $0.256 \mathrm{mg} / \mathrm{g} \mathrm{F}$.W. respectively) in the first season and $(0.742,0.405$ and 0.285 , respectively) in the second season, were obtained from treatment $\mathrm{F}-\mathrm{Th}_{6}+\mathrm{PEG} 15 \%$.

\subsection{Carbohydrate $(\%)$ in aerial part and roots}

The data appearing in Figs $(4: a, b \& c)$ for aerial part and $(5: a, b \& c)$ for roots pointed that the treatment $\mathrm{F}_{-} \mathrm{Th}_{6}$ gave the highest mean value of carbohydrate (\%) in the aerial part giving (31.93 and $38.48 \%)$ and in the roots (73.46 and 77.67\%) in both seasons, respectively, compared with control and other treatments. The treatment $\mathrm{H}_{2} \mathrm{O}_{2}$ at $10 \%$ gave the highest mean value of carbohydrate percentage for aerial part (30.74\%) in the first season, while the treatment of PEG $15 \%$ gave the highest mean value (37.34\%) for the aerial part in the second season. The treatment $\mathrm{H}_{2} \mathrm{O}_{2}$ at $10 \%$ gave the highest mean value of carbohydrates \% in roots (66.17 and $72.98 \%$ ) in both seasons, respectively.

Concerning the interaction treatments, we found that the treatment $\mathrm{F}-\mathrm{Th}_{6}+\mathrm{PEG} 15 \%$ gave the highest percentage of carbohydrate in aerial part with values (41.62 and 46.04\%) in the first and second season, respectively. The highest carbohydrate percentage $(66.17$ and $72.98 \%$ in both seasons, respectively) in roots was obtained from treatment $\mathrm{F}-\mathrm{Th}_{6}+\mathrm{H}_{2} \mathrm{O}_{2}$ at $10 \mathrm{mM}$. It was suggested that $\mathrm{H}_{2} \mathrm{O}_{2}$ mediates the regulation of photosynthesis by brassinosteroids (which are potent regulators of photosynthesis); also $\mathrm{H}_{2} \mathrm{O}_{2}$ regulate Calvin cycle and sugar metabolism via redox signaling and thus increase the photosynthetic potential (Jiang et al., 2012). 


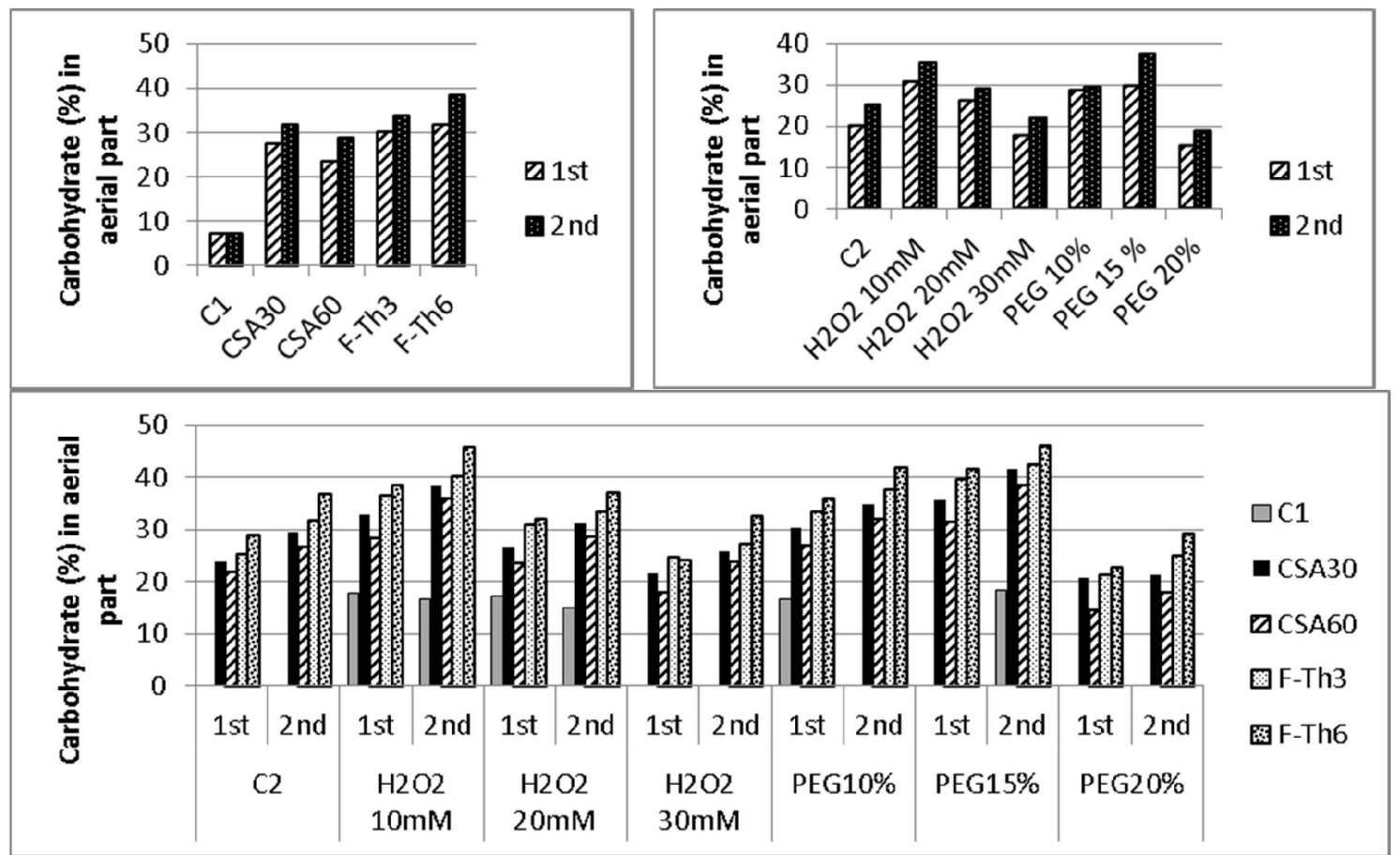

Fig. 4: Effect of seed dormancy breaking (a) and seed priming (b) treatment and their interaction (c) on carbohydrate (\%) in aerial part of Canna indica seedlings during $1^{\text {st }}$ and $2^{\text {nd }}$ season

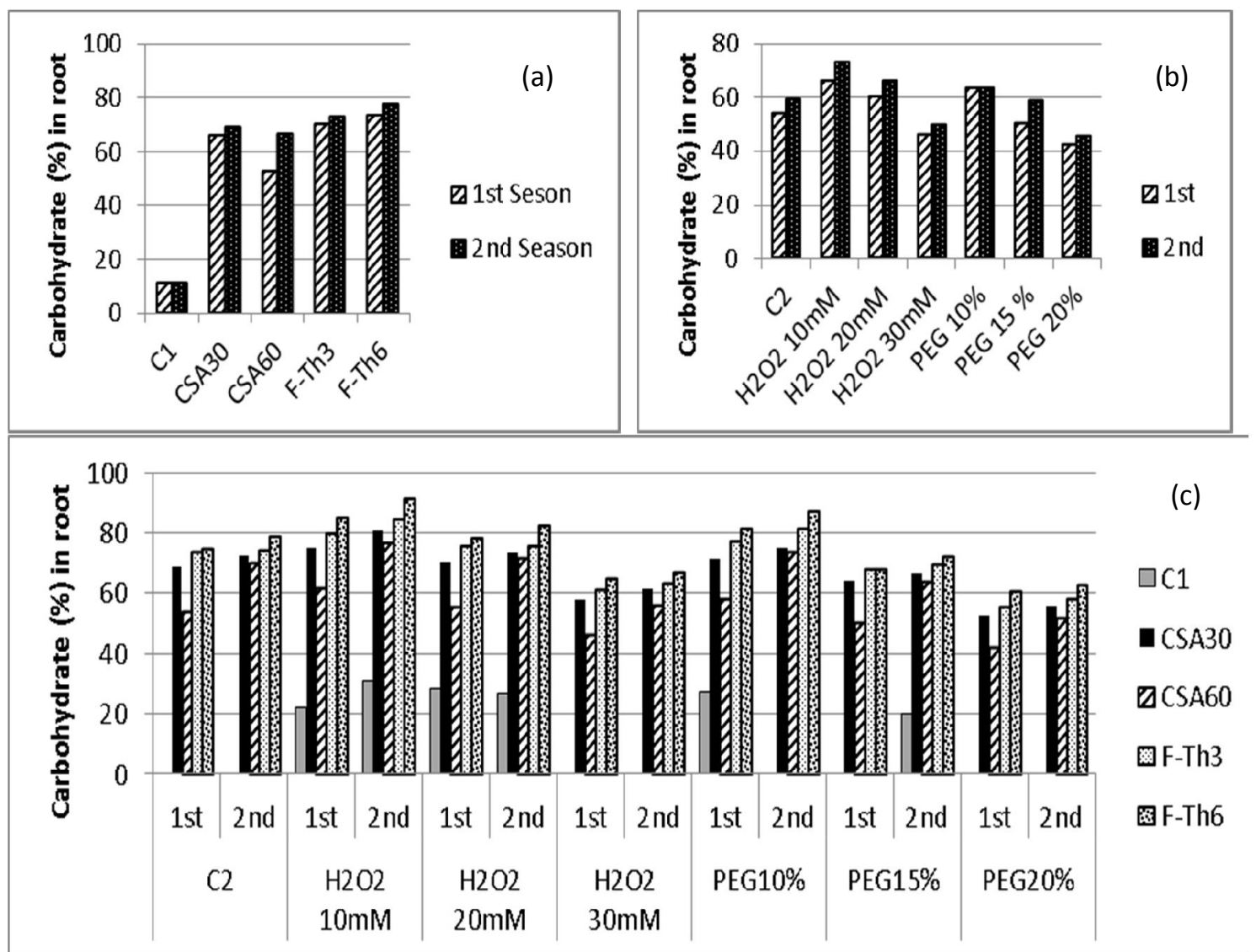

Fig. 5: Effect of seed dormancy breaking (a) and seed priming (b) treatment and their interaction (c) on carbohydrate (\%) in roots of Canna indica seedlings during $1^{\text {st }}$ and $2^{\text {nd }}$ season 


\subsection{Antioxidant activity (\%) in aerial part and roots}

The data presented in Figs (6: a, b\& c) for aerial part and Figs (7:a, b\& c) for roots stated that the treatment $\mathrm{F}-\mathrm{Th}_{6}$ produced highest activity of antioxidant in the aerial part giving ( 61.44 and $64.89 \%$ respectively, in the first and second seasons) and in roots (68.94 and 69.49\% respectively, in the first and second seasons) as compared with the control plants.

The seeds priming with $\mathrm{H}_{2} \mathrm{O}_{2}$ at $20 \mathrm{mM}$ gave the highest antioxidant activity in the different parts of the consequence seedlings, where the aerial part gave (54.90 and $62.99 \%$, respectively, in the first and second seasons) and roots (64.56 and 65.90\%, respectively, in the first and second seasons), compared with the control.

Concerning the interaction treatment, it is noticed that the treatment $\mathrm{F}-\mathrm{Th}_{6}+\mathrm{H}_{2} \mathrm{O}_{2}$ at $20 \mathrm{mM}$ gave the highest antioxidant activity in the resulted seedlings, the aerial part gave mean values ( 72.25 and $76.10 \%$, respectively, in the first and second seasons) and the roots gave (78.73 and $77.24 \%$, respectively, in the first and second seasons) compared with the control.

The results on antioxidant activity agrees with (Santhy et al., 2014) who found that $\mathrm{H}_{2} \mathrm{O}_{2}$ treatment increased the activity of antioxidant enzymes as compared to the control plants.

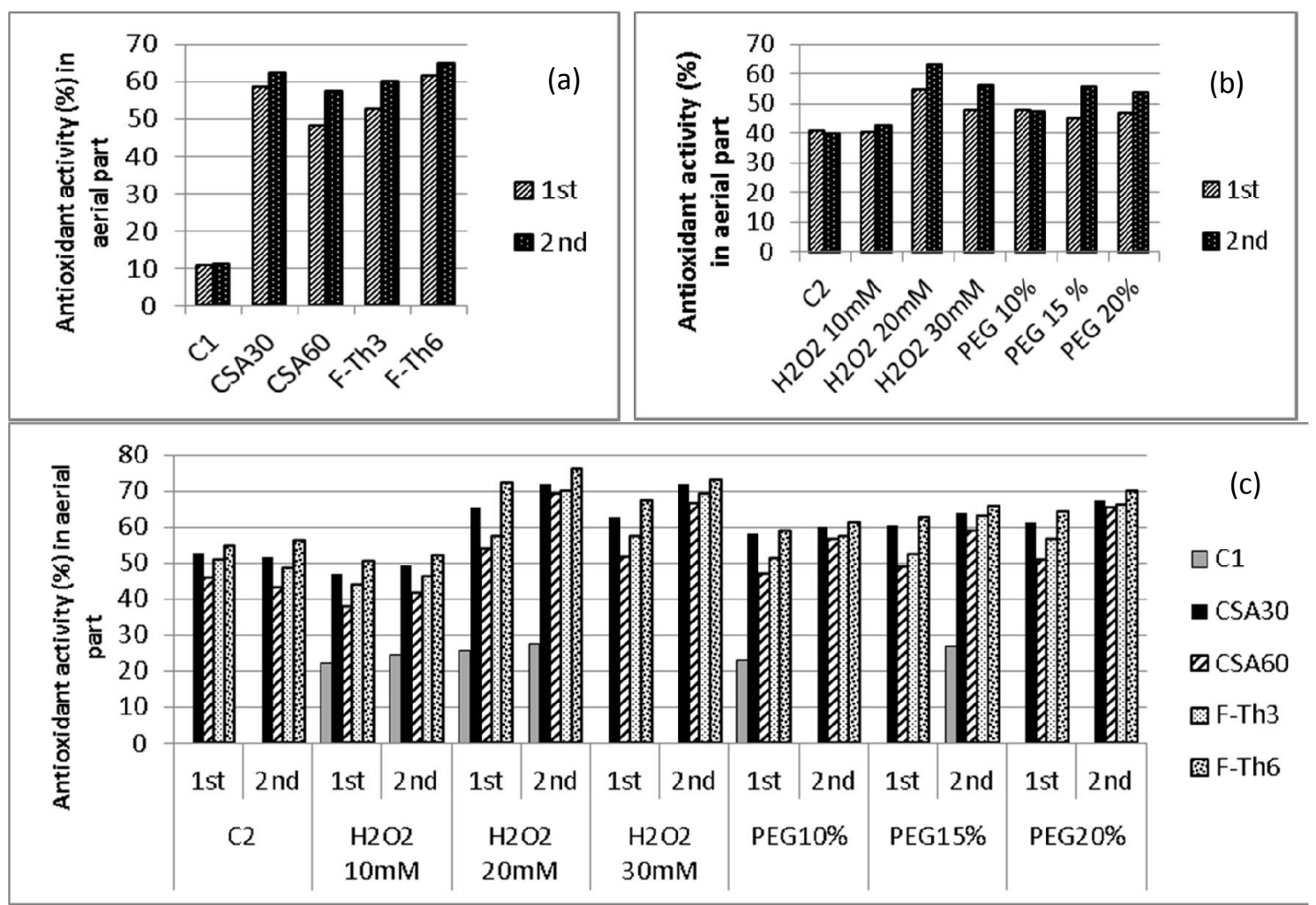

Fig. 6: Effect of seed dormancy breaking (a) and seed priming (b) treatment and their interaction (c) on antioxidant activity (\%) in aerial part of Canna indica seedlings during $1^{\text {st }}$ and $2^{\text {nd }}$ season 


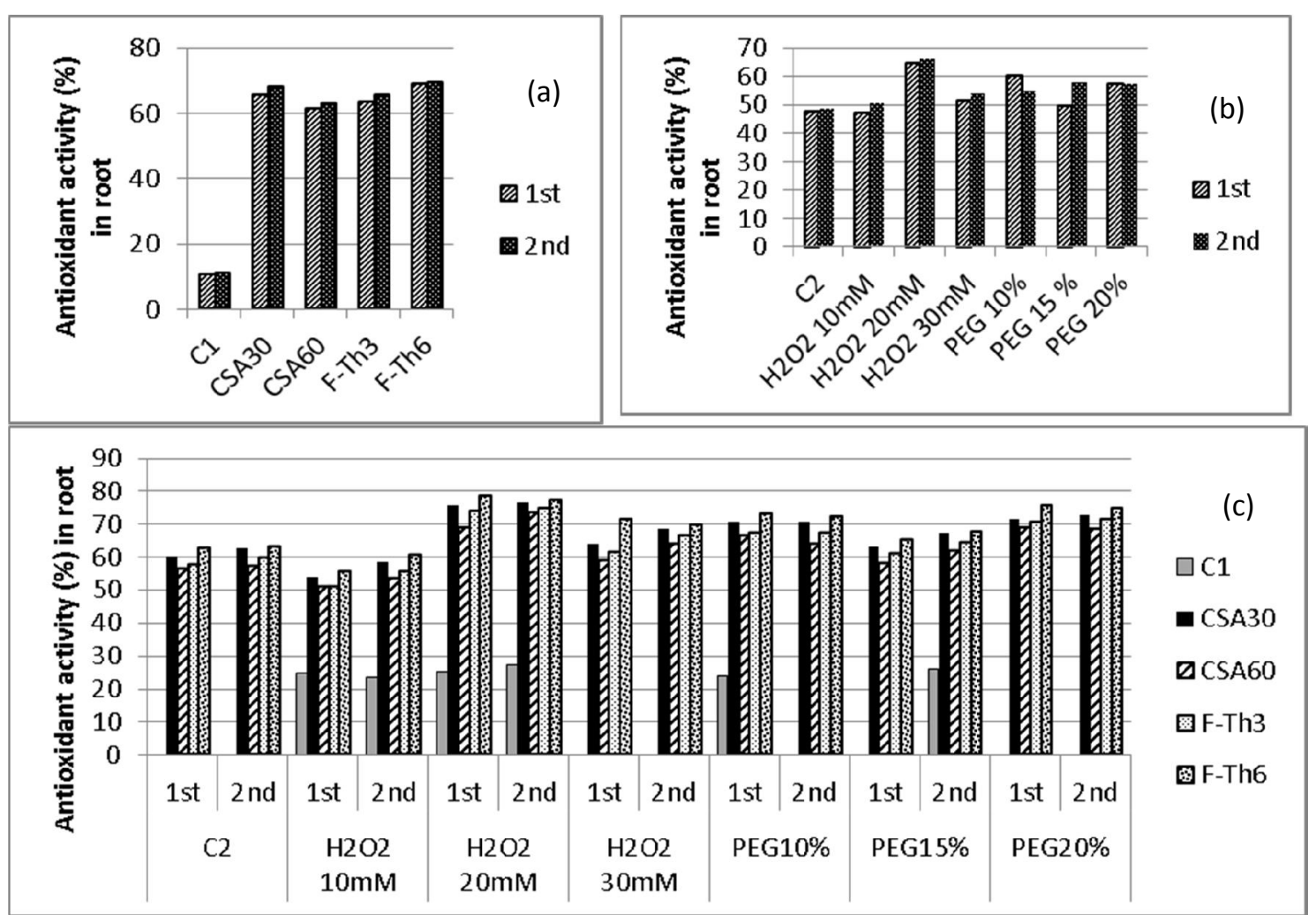

Fig. 7: Effect of seed dormancy breaking (a) and seed priming (b) treatment and their interaction (c) on antioxidant activity (\%) in roots of Canna indica seedlings during $1^{\text {st }}$ and $2^{\text {nd }}$ season

\section{Conclusion}

It is concluded that, the results of the present research clearly stated that the treated seeds to seed dormancy breaking with $\mathrm{F}_{-} \mathrm{Th}_{3}$ and $\mathrm{CSA}_{60}$ and treated the seeds with seed priming by $\mathrm{H}_{2} \mathrm{O}_{2}$ at $10 \mathrm{mM}$ gave a significant increase in all germination characters, while the interaction $\left(\mathrm{F}-\mathrm{Th}_{3}\right.$ or $\mathrm{CSA}_{60}+\mathrm{H}_{2} \mathrm{O}_{2}$ at $10 \mathrm{mM}$ )gave the same effect. Regarding the vegetative stage, the treatment with $\mathrm{F}^{-\mathrm{Th}_{6}}$ significantly increased all vegetative and chemical parameters. Type of treatment $\mathrm{H}_{2} \mathrm{O}_{2}$ at $20 \mathrm{mM}$ has an important effect on most characters. Applying of the interaction (F-Th ${ }_{6}+$ PEG $15 \%$ ) positively affected most of studied growth characters as well as chemical composition of canna indica L. seedlings.

\section{References}

Abdul Baki, A.A. and J.D. Anderson, 1973. Vigor determination in soybean seed by multiple criteria. Crop Science. 13: 630- 633.

Barba-Espin, G., P. Diaz-Vivancos, M.J. Clemente-Moreno, A. Albacete and L. Faize, 2010. Interaction between hydrogen peroxide and plant hormones during germination and the early growth of pea seedlings. Plant Cell Environ., 33: 981-994.

Breusegem, F.V., E. Vranova, J.F. Dat and D. Inze, 2001.The role of active oxygen species in plant signal transduction. Plant Science, 161: 405-414

Burits, M. and F. Bucar, 2000. Antioxidant activity of Nigella Sativa esserntial oil. Phtother. Res., 14: 323-328.

Çavusoglu, K. and K. Kabar, 2010. Effects of hydrogen peroxide on the germination and early seedling growth of barley under $\mathrm{NaCl}$ and high temperature stresses. EurAsian Journal of BioSciences 4: $70-79$.

Channegowda, S., A.A. Farooqi, K.N. Srinivasappa and M. Vasundhara, 2001. Studies on pregermination seed treatments in natural dye yielding tree (Caesalpinia sappan L.). Indian J. For., 24(3): 320-323. 
Chapman, H.D. and P.F. Pratt, 1961. Methods of analysis for soils, Plant and water. Div. Agric. Sci. Univ. of Calif., USA, 309p.

Ciciarelli, M.M., 2012. Life Cycle in Natural Populations of Canna indica L. from Argentina. Zhang X, editor. Phenology and Climate Change. Rijeka, Croatia: InTech; p. 101-116.

Dubois, M., K.A. Gilles, J.K. Hamilton, P.A. Rebers and F.F. Smith, 1956. Colorimetric method for the determination of sugars and related substances. Anal. Chem., 28: 350-356

El-Saifi, S.K., H.M.I. Ahmed, S.M. Hasan, M.M. Morsi and R.S. El-Shatoury, 2010. Seed priming influences seed germination and seedling growth of tomato under different salinity levels. J. of Plant Production, 1(2):159-170.

Esechie, H., 1994. Interaction of salinity and temperature on the germination of sorghum. Journal of Agronomy and Crop Science, 172: 194-199.

FAO, 2016. Canna edulis (http://ecocrop.fao.org/ecocrop/srv/en/cropView?id=2228)

Farahani, S.M., Z. Hajibarat and Z. Hajibarat, 2014. Effect of different treatments on breaking dormancy of Teucrium chamaedrys, L. seeds. Journal of Medicinal and By-products, 2014 (1):63-67.

Graven, P., C.G. Koster, J.J. Boon and F. Bouman, 1997. Functional aspects of mature seed coat of the Cannaceae. Plant Systematics and Evolution, 205(1): 223-240.

Gunarathna, M.H.J.P., A.I. Ranasinghe, S.C. Rathnayake and T.K. De Costa, 2016. Can Canna Indica Use as a Phytoremediation Agent in Mitigating High Pollution Concentrations in Reverse Osmosis Concentrate?. International Conference on Agricultural, Environmental and Civil Engineering (AECE-2016) Jan. 5-6, 2016 Kuala Lumpur (Malaysia), 46 - 52.

Hu, X.W., Y.R. Wang, Y.P. Wu, and C.C. Baskin, 2009. Role of the lens in controlling water uptake in seeds of two Fabaceae (Papilionoideae) species treated with sulphuric acid and hot water. Seed Science Research, 19(2): 73-80.

Jiang, Y., F. Cheng, Y. Zhou, X. Xia, W. Mao, K. Shi, Z. Chen and J. Yu, 2012. Hydrogen peroxide functions as a secondary messenger for brassinosteroids-induced $\mathrm{CO}_{2}$ assimilation and carbohydrate metabolism in Cucumis sativus. J Zhejiang Univ-Sci B (Biomed \& Biotechnol), 13(10):811-823

Kanase, V. and S. Vishwakarma, 2018. Treatment of Various Diseases by Canna indica L. - A Promising herb. Asian Journal of Pharmaceutical and Clinical Research, 11(12): 51 - 56.

Kessler, J.R., 2007. Canna Lilies for Alabama Gardens. Alabama Cooperative Extension System, Alabama A\&M University and Auburn University, ANR-1315, 1-10. [http://www.aces.edu/pubs/docs/A/ANR-1315/ANR1315.pdf] (accessed 24 June 2012).

Little, T.M., and F.J. Hills, 1978. Agricultural Experimentation - Design and Analysis. John Wiley and Sons, Inc., pp. 53-60.

Migahid, M.M., R.M. Elghobasy, L.M. Baidak and A.W. Amin, 2019. Priming of Silybum marianum (L.) Gaertn seeds with $\mathrm{H}_{2} \mathrm{O}_{2}$ and magnetic field ameliorates seawater stress. Heliyon, 5(6):1-9.

Mirmazloum, I., A. Kiss, É. Erdélyi, M. Ladányi, É.Z. Németh and P. Radácsi, 2020. The effect of osmopriming on seed germination and early seedling characteristics of Carum carvi $\mathrm{L}$. Agriculture, 10 (94): 2- 11.

Moran, R., 1982. Formulae for determination of chlorophyllous pigments extracted with n,ndimethylformamide. Plant Physiol, 69: 1376-1381.

Nagarajan, S., V.K. Pandita, D.K. Joshi, J.P. Sinha and B.S. Modi, 2005. Characterization of water status in primed seeds of tomato (Lycopersicon esculentum Mill.) by sorption properties and NMR relaxation times. Seed Sci. Res., 15: 99-111

Nasr, S.M.H., S.K. Savadkoohi and E. Ahmadi, 2013. Effect of different seed treatments on dormancy breaking and germination in three species in arid and semi-arid land. Forest Science and Practice, 15(2): $130-136$.

Orchard, T., 1977. Estimating the parameters of plant seedling emergence. Seed Science and Technology, 5: 61-69.

Paparella, S., S.S. Araújo, G. Rossi, M. Wijayasinghe, D. Carbonera and A. Balestrazzi, 2015. Seed priming: state of the art and new perspectives. Plant Cell Reports, 34: 1281-1293.

Pullaiah, T., 2006. Encyclopaedia of World Medicinal Plants. New Delhi, India, I: Regency Publication, 421. 
Salah, S.M., G. Yajing, C. Dongdong, L. Jie, N. Aamir, H. Qijuan, H. Weimin, N. Mingyu and H. Jin, 2015. Seed priming with polyethylene glycol regulating the physiological and molecular mechanism in rice (Oryza sativa L.) under nano-ZnO stress. Scientific Reports, 5 (14278): 1 14.

Santhy, V., M. Meshram, R. Wakde and V. Kumari, 2014. Hydrogen peroxide pre-treatment for seed enhancement in cotton (Gossypium hirsutum L.). African Journal of Agricultural Research, 9(25): 1982-1989.

Scott, S., R. Jones and W. Williams, 1984. Review of data analysis methods for seed germination. Crop Science, 24: 1192-1199.

Stout, D.G., 1990. Effect of freeze-thaw cycles on hard-seededness of alfalfa. J Seed Technol:14(1):4755.

Tiryaki, I. and M. Topu, 2014. A novel method to overcome coat-imposed seed dormancy in Lupinus albus L. and Trifolium pratense L. Journal of Botany, 2014 (ID: 647469): 1-6.

Vankar, S. P. and J.Y. Srivastava, 2018. A review-canna the wonder plant. Journal of Textile Engineering \& Fashion Technology, 4(2): $158-162$.

Zeng, L.W., P.S. Cocks, S.G. Kailis, and J. Kuo, 2005. The role of fractures and lipids in the seed coat in the loss of hard seededness of six Mediterranean legume species. Journal of Agricultural Science, 143(1): 43-55.

Zhang, F., J. Yu, C.R. Johnston, Y. Wang, K. Zhu, F. Lu, Z. Zhang and J. Zou, 2015. Seed priming with polyethylene glycol induced physiological changes in sorghum (Sorghum bicolor L. Moench) seedlings under suboptimal soil moisture environments. Plose one, 10(10):1-15. 